\title{
Ensino Religioso na escola pública brasileira e a questão da laicidade
}

\author{
Religious Education in the brazilian public school and the issue of secularism
}

\author{
Paulo Agostinho Nogueira Baptista* \\ Giseli do Prado Siqueira**
}

\begin{abstract}
Resumo
A presença do componente curricular Ensino Religioso - ER na escola, de modo especial na escola pública, é marcada pela controvérsia. O Brasil viveu sob o manto da confessionalidade, mesmo depois do decreto n. 119A (1890), e a separação legislativo-jurídica entre Igreja e Estado não pôs fim ao problema. A partir dessa perspectiva, o objetivo deste artigo é refletir sobre a configuração atual do Ensino Religioso na escola pública, a partir de breve referência inicial aos antecedentes históricos e aos aspectos filosóficos deste processo, que permitiram essa situação, desde a implantação do regime republicano no país. Quer considerar o problema de o Ensino Religioso estar sempre marcado por um discurso conflitivo entre os pressupostos da laicidade e da confessionalidade. $O$ itinerário foi norteado pela seguinte questão: como analisar as mudanças e alterações que fizeram com que este componente curricular passasse da área eclesiástica para a esfera pública? Será que o Ensino Religioso é um problema para a laicidade? A metodologia utilizada é a pesquisa bibliográfica, qualitativa e documental, através da análise de documentos constitucionais, leis de diretrizes e bases da educação, pareceres e resoluções que envolveram esse componente curricular, bem como discursos de juristas em diversas épocas. Ao se investigar este tema, percebe-se que a discussão sobre o Ensino Religioso, bem como a compreensão de sua presença na escola pública, envolve uma complexa discussão, que não pode desconhecer os aspectos históricos, filosóficos e jurídicos.
\end{abstract}

Palavras-chave: Ensino Religioso. Laicidade. Confessionalidade.

\begin{abstract}
The presence of the Religious Education component in the school's curriculum, especially in public schools, is marked by controversy. Brazil lived under the veil of confessionality, even after enactment number 119A (1890) and the legislativelegal separation between Church and State did not put an end in the problem. From this perspective, the objective of this article is reflecting on the current configuration of religious education in public schools, from a brief initial reference to the historical background and the philosophical aspects of this process, which allowed this situation, since the implantation of the republican regime in the country. Considering the problem that Religious Education is always marked by a conflictive discourse between the assumptions of secularity and confessionality. The itinerary was guided by the following question: how to analyze the changes and alterations that made this curricular component move from the ecclesiastical area to the public sphere? Is Religious Education a problem for secularity? The methodology used is the bibliographic, qualitative and documentary research, through the analysis of constitutional documents, laws of guidelines and bases of education, as well as opinions and resolutions that involved this curricular component, as well as speeches of jurists in different periods. When investigating this theme, it is clear that the discussion on Religious Education, as well as the understanding of its presence in public schools, involves a complex discussion, which can not ignore the historical, philosophical and legal aspects.
\end{abstract}

Keywords: Religious Education. Secularity. Confessionality.

\footnotetext{
Artigo submetido em 14 de junho de 2019 e aprovado em 22 de dezembro de 2019.

* Doutor em Ciência da Religião pela UFJF. Professor do PPGCR PUC Minas. País de origem: Brasil. E-mail: pagostin@gmail.com

** Doutora em Ciência da Religião pela PUC-SP. Professora do PPGCR PUC Minas. País de origem: Brasil. E-mail: gisiqueirasoph@gmail.com
} 


\section{Introdução}

O tema do Ensino Religioso na Escola Pública, desde o final do século XVIII, mas especialmente a partir do século XIX, provocou grande conflitividade, verdadeira luta entre aqueles que defendiam um ensino laico e os que queriam a permanência desse espaço e tempo da confessionalidade.

A questão não dizia respeito aos ensinamentos morais, que tanto um grupo quanto o outro se uniam em defender, mas na perspectiva dessa moralidade, a ser trabalhada com crianças, adolescentes e jovens: ser oferecida de forma laica ou cristã, que era a tradição religiosa majoritária, especialmente a católica.

Condorcet afirmava em 1791 que “a educação pública é um dever da sociedade para com os cidadãos. [...] em vão as leis teriam respeitado esse primeiro princípio da justiça eterna, se a desigualdade nas faculdades morais impedisse o maior número de usufruir desses direitos em toda sua extensão" (CONDORCET, 1994, p. 14). ${ }^{1}$ Era direito de todos ter acesso ao ensino público e laico, e um ensino amplo, que incluísse a dimensão política, moral e até religiosa: "a educação, se tomada em toda a sua extensão, não se limita à instrução positiva, ao ensino de verdades e cálculos, mas abrange todas as opiniões políticas, morais e religiosas” (Ibid. p. 35).² Porém, ele chama a atenção para um problema fundamental, que representava o enfrentamento do ensino confessional: "As autoridades públicas não têm o direito de vincular o ensino da moral ao da religião”. (Ibid. p. 37). 3

A temática deste artigo gira em torno desse debate entre confessionalidade e laicidade do Ensino Religioso na Escola Pública brasileira. A existência do Ensino Religioso no ensino público seria uma ameaça à laicidade? Ou, por si só, o Ensino Religioso já se caracteriza por ser confessional?

\footnotetext{
${ }^{1}$ L'instruction publique est un devoir de la société à l'égard des ci-toyens; vainement les lois auraient-elles respecté ce premier principe de l'éternelle justice, si l'inégalité dans les facultés morales empêchait le plus grand nombre de jouir de ces droits dans toute leur étendue. [trad. dos autores].

${ }^{2}$ D'ailleurs, l'éducation, si on la prend dans toute son étendue, ne se borne pas seulement à l'instruction positive, à l'enseignement des vérités de fait et de calcul, mais elle embrasse toutes les opinions politi-ques, morales ou religieuses. [trad. dos autores].

${ }^{3}$ La puissance publique n'a pas droit de lier l'enseignement de la morale à celui de la religion. [trad. dos autores].
} 
Historicamente, há grande dificuldade de se entender esse componente curricular, não só pelo seu percurso desde o Brasil Colônia, mas principalmente em razão do adjetivo que qualifica o substantivo ensino: "religioso". Associa-se imediatamente que se trata de questões vinculadas à religião, quando não de "ensino de religião". Esquece-se que o religioso, ou mais propriamente a "religiosidade", enquanto categoria antropológica, mostra uma dimensão de sentido, inerente à condição humana. Ou seja, o humano busca, procura e precisa de sentidos para viver. E esses sentidos não são necessariamente religiosos (GRUEN, 1974; SIQUEIRA, 2012; BAPTISTA, 2015). Os ateus e agnósticos também vivem com sentidos, não religiosos. E ao se postular essa visão, também não se quer dizer que o Ensino Religioso - ER na Escola Pública seria um "ensino estatal”, ou a visão do Estado sobre a religião, ou ainda uma doutrinação do Estado sobre a/as religião/ões.

Tudo que existe na educação é processo formativo. Todas as ciências, conhecimentos humanos, sabedorias, tradições e costumes são objeto de reflexão, de análise, de crítica honesta, em busca da verdade, que não pode se reduzir a uma única visão, a uma única posição. Assim como a biodiversidade da natureza, a condição humana é diversa e plural. E algumas das teorias e concepções, em quaisquer campos, produzem controvérsias, debates e devem suscitar o diálogo e o respeito por aqueles e aquelas que as defendem, mesmo que não as aceitemos e concordemos com elas. E o fenômeno da crença e da não crença, como o seu estudo, não foge desse problema. E é grande oportunidade para o exercício da tolerância, do diálogo, do respeito e da construção de relações de convivência e de paz.

Para abordar o tema deste artigo, o caminho a ser percorrido recuperará alguns antecedentes históricos do Brasil, da Colônia, do Império à República, de modo a se compreender como se construiu a discussão entre a confessionalidade e a laicidade a respeito do Ensino Religioso. A parte final trará a discussão mais recente sobre esse componente curricular e a trajetória que propiciou sua inclusão na Base Nacional Comum Curricular - BNCC e a criação de Diretrizes Curriculares Nacionais - DCNs para a formação inicial dos docentes de Ensino Religioso. 


\section{Antecedentes históricos do Ensino Religioso no Brasil}

O componente curricular Ensino Religioso, garantido no sistema escolar, em fases distintas da educação brasileira, quase sempre se configurou na prática como “ensino de religião”. Há a suposição que, no Brasil, a herança colonial teve fortes influências nessa composição, mas não é a única explicação desta realidade. Admitese como hipótese que a incompreensão de laicidade foi estabelecida na separação entre Igreja e Estado e os reflexos de certo obscurantismo contribuíram para reafirmar mais conflitos do que dirimir dúvidas sobre o papel e o objeto desta área de conhecimento no ambiente escolar.

Recompor este cenário a partir de referência, mesmo que breve, aos antecedentes históricos permitirá localizar o Ensino Religioso - ER no tempo histórico, bem como identificar os desdobramentos decorrentes da instauração da República no Brasil.

Pode-se dizer que inicialmente esta disciplina foi marcada profundamente pelo traço da Cristandade, como herança da colonização, mas sofreu alterações com a implantação do regime republicano, fundamentado em princípios de liberdade, inclusive da liberdade religiosa.

A compreensão histórica da implantação do regime republicano e a implementação das leis educacionais, as quais contemplam o Ensino Religioso, trazem interpretações diferenciadas quanto ao princípio da liberdade religiosa do cidadão e da laicidade do Estado, criando correntes de posições favoráveis e contrárias à sua permanência no sistema escolar.

Para compreender esse processo histórico é importante perceber que, no Brasil colonial, o Ensino Religioso era efetivado como cristianização, por delegação pontifícia ao poder estabelecido. Compreendido como "ensino de religião", sua efetivação era questão de cumprimento dos acordos estabelecidos entre a Igreja Católica e o monarca de Portugal, em decorrência do Regime de Padroado, que garantia aos representantes eclesiásticos plenos poderes em ações políticas e jurídicas. 
A estruturação educacional do país, iniciada pelos missionários jesuítas ${ }^{4}$, franciscanos e outros religiosos, atendia a esses interesses coloniais, e a chamada “instrução religiosa" era, e não podia deixar de ser nesse contexto, de índole confessional católica, como ficava evidente pelo conteúdo doutrinário de sua programação e a prática religiosa proposta. Seu caráter propriamente educativo pendia para a formação moral. O que pode ser reconhecido como Ensino Religioso Confessional.5 No caminho percorrido pelo Ensino Religioso deve-se destacar, inicialmente, que esta nomenclatura também é resultado de um processo histórico, de associação entre ensino e religião. Uma das explicações plausíveis foi apresentada por Wolfgang Gruen (2004), no verbete Ensino Religioso, elaborado para um Dicionário de Catequética:

No séc. XVIII ocorre um desdobramento de especial interesse para nós: em 1774, no âmbito de uma ampla reforma do ensino, obra do Pe. Johann von Felbiger, a imperatriz Maria Teresa, da Áustria, prescreveu 6 anos de ensino fundamental para todas as crianças, e nele, como conteúdo curricular, o estudo do catecismo, já em uso nas escolas, mas só como texto de leitura. Outros países seguiram o exemplo. Para compreender essa inovação, é preciso vê-la em seu contexto. O desenvolvimento do comércio e da indústria exigia nova forma de Estado: centralizado, consolidado pela distribuição de poderes na base não mais de privilégios (em favor de corporações ou da Igreja) e sim de instituições. Ao mesmo tempo, com o Iluminismo, amadurece a passagem da cultura europeia de feitio eclesiástico, teológico, para uma cultura emancipada, ávida de saber, de ordem e progresso, agressiva contra todo tipo de ignorância, intolerância, infantilização de adultos. O Estado foi açambarcando os serviços básicos da sociedade, inclusive o controle da religião. Desde a Paz de Vestfália (1648), cada região determinava qual a sua religião oficial, submetida ao Estado. Na Áustria, católica, aos olhos de muitos, o ER obrigatório na escola parecia valorizar a religião e dar boa chance de ensinar o catecismo a todas as crianças. Em tempos de cristandade, é compreensível que o estudo do catecismo fosse considerado catequese: família e sociedade proporcionavam o cultivo informal, ambiental, da fé; o ensino da doutrina cristã servia-lhe de complementação nocional. Mais formativo que o catecismo em si, era o fato de frequentá-lo: constituía-se importante símbolo de pertença eclesial. (GRUEN, 2004, p. 413).

\footnotetext{
${ }^{4}$ Na História da Educação Brasileira, muitas vezes, registra-se apenas a presença dos jesuítas como evangelizadores e educadores. Em ampla pesquisa realizada em centros de documentação para sua tese de doutorado, Luiz Fernando Conde Sangenis mostra a ação educacional e missionária dos franciscanos no Brasil, desde 1500, procurando tirá-la do esquecimento. Lembrando que "de fato, os jesuítas empreenderam no Brasil uma significativa obra missionária e evangelizadora, especialmente fazendo uso de novas metodologias, das quais a educação escolar foi uma das mais poderosas e eficazes. Em matéria de educação escolar, os jesuítas souberam construir a sua hegemonia. Não apenas organizaram uma ampla 'rede' de escolas elementares e colégios, como o fizeram de modo muito organizado, contando com um projeto pedagógico uniforme e bem planejado, sendo o 'Ratio Studiorum' a sua expressão máxima. Os autores que tematizaram a História da Educação Brasileira, ao considerarem tão expressiva a ação educativa dos jesuítas, entre 1549 e 1759 , caracterizaram esse lapso de mais de dois séculos pelo presumível exclusivismo jesuítico, apesar do protagonismo - em geral, ignorado ou silenciado - de franciscanos, de beneditinos, de carmelitas, de mercedários, de oratorianos e de outros religiosos na cena educacional brasileira." (SANGENIS, 2006, p. 23).

${ }^{5} \mathrm{O}$ vocábulo "confessional" passou a ser expressão tipicamente utilizada por instituições religiosas, de modo especial pela Igreja Católica, que, através do encarte do Boletim Semanal, explicita o sentido desse termo aplicado ao Ensino Religioso: "Pressupõe um ensino entre grupos de uma mesma confissão religiosa, incluindo doutrina, visão de ser humano em relação ao sagrado, incluindo cultos de sua denominação, ritos, princípios ético-morais, costumes, organização interna, papel da autoridade religiosa; nesse sentido pressupõe que todos os(as) educandos(as) e educadores(as) pertençam à mesma confissão religiosa". (CONFERÊNCIA NACIONAL DOS BISPOS DO BRASIL CNBB, 1996). Para facilitar a referência dessa instituição se utilizará a partir daqui a sigla CNBB.
} 
Em outras palavras, o Ensino Religioso torna-se escolar no currículo da Áustria, visando o estudo do catecismo. Há uma associação direta entre ensino e religião, predominantemente a religião cristã católica. Gruen (2004) destaca que a permanência ao modelo de Felbiger se deve à presença religiosa na sociedade, reafirmada pela concretude de símbolos e pelo ambiente global para educar a criança na fé. Gruen reconhece os desafios de aceitação do Ensino Religioso em outras localidades da Europa, e que na França esse modelo teve resistência: "o ministro da educação, Jules Ferry, em nome da laicidade do Estado, retirou o ER da escola oficial (1882); em seu lugar colocou Moral e Educação Cívica.” (GRUEN, 2013, p. 129)

Diante das considerações de Wolfgang Gruen é possível perceber que esses discursos conflitivos revelam posicionamentos contrários e favoráveis à permanência do Ensino Religioso no currículo escolar, e essa realidade não é privilégio de brasileiros. Na Europa, essas manifestações já estavam presentes nas reformas educacionais. E sinalizavam que os princípios morais são importantes na formação de pessoas no ambiente escolar, reforçando o que era repassado pela sociedade e pela família, e não mais apenas os valores religiosos, demonstrando assim o enfraquecimento das relações entre Igreja e Estado.

Ao explorar este contexto das reformas educacionais europeias, e em especial a francesa, depara-se com associações estabelecidas entre as mudanças regimentares nas escolas e a origem do termo laicidade ${ }^{6}$. O sociólogo Baubérot7, dentre várias origens para o termo laicidade, em espaços nacionais e momentos históricos, destaca que o termo foi inventado nos anos 1870 e a primeira definição foi de Ferdinand Buisson, filósofo, diretor do ensino fundamental na época em que Jules Ferry laicizou a escola pública: afirmou que a laicidade consistia no Estado independente de todo culto e de todo clero, com o objetivo de realizar a liberdade de todos os cultos e a igualdade de todos os cidadãos perante a lei, independentemente da sua filiação religiosa. Essa definição pode ser aplicada a um certo número de países. Na França, a laicidade se tornou a recusa de quaisquer expressões da religião na esfera pública. (BAUBÉROT, 2008 apud SIQUEIRA, 2012, p.23). ${ }^{8}$

\footnotetext{
${ }^{6}$ Para Pena-Ruiz, laicidade teria a seguinte origem: "simples laïc (laico, leigo), desde a época medieval, é o homem do povo, crente ou não, distinto do clérigo, que, quanto a ele, é depositário de uma função reconhecida na administração do sagrado. O princípio laico de união do povo, ver-se-á, traduz a indiferenciação dos simples "laïcs" em valores fundadores da Cité (comunidade, cidade): liberdade de consciência, igualdade de todos, indivisibilidade de um corpo político fundado sobre a identidade universal dos direitos detidos por cada um. Tal princípio não é de forma alguma contraditório em relação à fé religiosa, uma vez que constrói a ordem política, ao fazer abstração das posições espirituais dos indivíduos". (PENA-RUIZ, 2004, p. 1).

7 Em "Laicidades sem fronteiras" (Laïcités sans frontières), os sociólogos Bauberót e Milot apresentam distintas formas em que a laicidade se apresenta em espaços nacionais e momentos históricos (BAUBÉROUT; MILOT, 2011).

${ }^{8}$ Conferir, também, Baubérot (2008).
} 
Essas concepções também podem ser percebidas, numa leitura de aportes filosóficos e jurídicos, no Brasil Imperial, mesmo que ainda perpetuasse o Regime do Padroado como concessão, mas quando já era visível seu enfraquecimento. É também perceptível que o pensamento de Ferdinand Buisson influenciou “os escritos e as atividades de figuras da elite intelectual brasileira, especialmente Rui Barbosa e Menezes Vieira.” (BASTOS, 2013, p. 231). E, posteriormente, até o movimento reformador proposto pelo Manifesto dos Pioneiros da Escola Nova, que clamará por uma educação voltada para todos.

Rui Barbosa propõe no Brasil a reforma do ensino primário e de várias instituições complementares da instrução pública em 1883. E a questão religiosa perpassava uma linha tênue entre sua formação cristã e os ideais que agora o inspiravam. Quando defende a Escola Leiga ele diz: "instituída assim, a escola comum não imporá dogmas, religiosos ou irreligiosos, materialistas ou espiritualistas, deístas e ateus, racionalistas ou confessionais”. (BARBOSA, 1947, p. 327s).

Além das influências francesas, é relevante destacar que nos Estados Unidos a laicidade era, como continua sendo, princípio de liberdade religiosa, presente em sua Constituição que se tornou referência para muitas interpretações passadas e atuais. $\mathrm{O}$ Estado federativo americano se separa de todas as religiões e garante aos cidadãos a plenitude de sua liberdade religiosa, devendo, antes de tudo, não atentar contra essa liberdade. Bressler e Semard destacam que

no artigo VI(3) está escrito: "nenhuma profissão de fé religiosa será exigida como condição de aptidão às funções e cargos públicos sob autoridade dos Estados Unidos" e a propósito das responsabilidades do Congresso, está claramente dito que ele: "não poderá outorgar nenhuma lei tendo como objeto estabelecer uma religião ou proibir o livre exercício". (BRESSLER; SEMARD, 2006, p. 96).

O pensamento francês e o pensamento americano, portanto, influenciaram diretamente a elaboração e a interpretação da Constituição republicana brasileira. Mas tal marca começou antes, ainda no Império, num processo que culminaria com a República e a Separação entre Igreja Católica e Estado, particularmente com o Decreto n. 119A, de 1890. 
E para se compreender esse processo, optou-se neste artigo pelos documentos e análises publicadas na época e em anos subsequentes à separação entre Igreja e Estado, efetivada pelo Decreto n॰119-A. O intuito principal é entender a passagem da Instrução Religiosa ao Ensino Religioso Escolar e as rupturas necessárias para a construção epistemológica desse componente curricular, jogando luz para desvelar o paradoxo entre o Ensino Religioso confessional e do não confessional.

\section{A separação entre Igreja e Estado no Brasil: o conflito entre confessionalidade e laicidade}

A separação entre Igreja e Estado no Brasil guarda relação direta com acontecimentos do início do século XIX, de modo especial com a situação que levou o Príncipe-regente de Portugal a vir para o Brasil, no contexto do bloqueio de Napoleão Bonaparte ao comércio dos europeus com a Inglaterra e a ameaça de invasão de Portugal, através da Espanha, pela recusa dos portugueses em aderir ao bloqueio continental.

A chegada de Dom João VI no Brasil, em 1808, fruto de acordo com o rei inglês Jorge III, criou uma situação diferente para a lógica do Padroado Régio. Como os portugueses precisaram da proteção inglesa para a viagem, houve um acordo que previa uma contrapartida que seria definida em Tratado. Uma das exigências da Grã Bretanha era que houvesse liberação para a celebração religiosa de cultos pelos britânicos. O Tratado de Amizade, Comércio e Navegação, que Portugal assinou com a Grã Bretanha, em fevereiro de 1810, abriu esse espaço: trouxe "liberdade de Consciência, e licença para assistirem, e celebrarem o Serviço Divino em honra do Todo Poderoso Deos”, de modo a não serem molestados, perturbados ou perseguidos por causa de sua religião, desde que esse culto fosse doméstico, "dentro de seus Domínios”, e as igrejas ou capelas tivessem a aparência de uma habitação (BRASIL, 1810). Tal acordo não deixou de provocar a reação católica, até com ameaça de excomunhão (CUNHA, 2013).

A constituição de 1824, proclamada em nome da Santíssima Trindade, em atendimento às exigências inglesas, em seu art. $5^{\circ}$ diz: "A Religião Catholica Apostolica Romana continuará a ser a Religião do Imperio. Todas as outras Religiões serão permitidas com seu culto domestico, ou particular em casas para isso 
destinadas, sem fórma alguma exterior do Templo.” (BRASIL, 1824). Portanto, começa uma dinâmica que irá se definindo até chegar à República.

Um dos primeiros textos legislativos no Brasil que fazem referência ao ensino da religião é a Lei de 15 de outubro de 1827. No seu art. 6º trata do conteúdo a ser ensinado: “as quatro operações de arithmetica, pratica de quebrados, decimaes e proporções, as noções mais geraes de geometria pratica, a grammatica da lingua nacional, e os principios de moral christã e da doutrina da religião catholica e apostolica romana" (BRASIL, 1827). Como se observa, não se fala de Ensino Religioso, mas do ensino da moral e da doutrina católica. Por exemplo, o Regimento do Colégio Pedro II, criado em dezembro de 1837, no capítulo XV, mostra como seria a "Instrucção Religiosa", desde a primeira série, chamada de $8^{\mathrm{a}}$ aula, com estudantes a partir de 8 anos de idade. Conforme Zotti (2005, p. 36), nos oito anos desse ensino havia a previsão detalhada de formação religiosa católica, "parte do currículo de cada série”, o que pode ser demonstrado na citação abaixo, tirada do Regulamento (BRASIL, 1838, Cap. XV, p. 74-75):

Art. 87. Além da Missa, homilia orações de véspera, que são comuns para todo o Collegio, os alunos da aula $8^{\mathrm{a}}\left(1^{\mathrm{a}}\right.$ série) decorarão historia sagrada e pedaços do Novo e Velho Testamento que lhe serão explicados pelo capelão. Art. 88. Os das aulas $7^{\mathrm{a}}$ e $6^{\mathrm{a}}\left(2^{\mathrm{a}}\right.$ e $3^{\mathrm{a}}$ séries $)$ decorarão o catecismo da diocese, com as explicações que o capelão julgar necessárias.

Art. 89. Os alunos das aulas $5^{\mathrm{a}}, 4^{\mathrm{a}}, 3^{\mathrm{a}},\left[4^{\mathrm{a}}, 5^{\mathrm{a}}, 6^{\mathrm{a}}\right.$ séries $]$ assistirão exposição dos dogmas da religião e das provas em que se apoião.

Art. 90. Para as aulas $2^{\mathrm{a}}$ e $1^{\mathrm{a}}\left(7^{\mathrm{a}}\right.$ e $8^{\mathrm{a}}$ séries $)$ haverá conferencias philosophicas sobre a verdade da Religião, sua historia, e os benefícios, que lhe deve a humanidade. 9

Outro decreto, de número 2006, de 24 de outubro de 1857, traz alteração nosRegulamentos dos colégios públicos de instrução secundária, e manterá a formação dessa forma: "O ensino da doutrina christã e historia sagrada", sob responsabilidade do “capellão”. (BRASIL, 1857). Segundo Cecchetti (2016, p. 112113), aqui começaria uma mudança significativa: "um processo de 'disciplinarização' do 'ensino da religião', com seu respectivo enquadramento dentro das fronteiras simbólicas de uma disciplina”. E o Decreto n. 2.434, de 22 de junho de 1859, pela primeira vez fará referência à expressão "ensino religioso", ao criar "huma cadeira para o ensino religioso no Imperial Collegio de Pedro Segundo”. (BRASIL, 1859). E as mudanças no terceiro quarto do séc. XIX não pararão. Em 1878, pelo decreto n.

\footnotetext{
${ }^{9}$ Ver também Moacyr (1936).
} 
6.884, houve a possibilidade de os alunos não católicos não participarem da “instrucção religiosa" (BRASIL, 1878). Observa-se que "É a primeira vez que a legislação imperial reconheceu a existência de estudantes 'acatólicos', apesar dos protestantes há tempo reivindicarem o direito à liberdade de culto.” (CECCHETTI, 2016, p. 115). E com a confirmação dessa posição pelo decreto n. 7.427 , de 1879 , “criou-se a possibilidade da sua 'facultatividade', sendo, a partir de então, oferecido 'fora' dos horários destinados às demais disciplinas científicas”. (CECCHETTI, 2016, p. 115-116).

Com o fim do Império, através de golpe militar com apoio civil, e o início da República, começa-se nova perspectiva para as relações entre Estado e Igreja Católica. O governo provisório promulga o Decreto 119A, em 07 de janeiro de 1890, com a extinção do Padroado Régio (art. $4^{\circ}$.), que determina a separação entre Estado e Igreja, legislação até anterior à lei francesa, que é de 1905, e dá início a um conflito que continuará por décadas. Além dessa revogação, o Decreto afirma a liberdade de crença e que o Estado não deve interferir em suas crenças e suas disciplinas. Trata ainda do fim de qualquer discriminação em razão de crença religiosa ou visão filosófica, e que essas instituições de natureza religiosa não devem sofrer contrariedades em seus "actos particulares ou públicos”. (BRASIL, 1890).

Esse Decreto foi promulgado antes da nova Constituição, que foi publicada em 24 de fevereiro de 1891 (BRASIL, 1891). Da sua redação participaram Rui Barbosa e Prudente de Morais. Já em 1876, Rui Barbosa se posicionara sobre a liberdade religiosa dizendo que religião e liberdade têm mútua dependência. Ele mesmo confirma isso em Discurso no Colégio Anchieta, em 1903, mostrando sua posição contrária ao modelo francês de laicidade:

o constitucionalismo americano repele essa uniformidade atéia, cuja superstição professa a República no Brasil, e que não estava decerto nos intuitos dos seus fundadores. Desde 1876 que eu escrevia e pregava contra o consórcio da Igreja com o Estado; mas nunca o fiz em nome da irreligião: sempre, em nome da liberdade. Ora, liberdade e religião são sócias, não inimigas. Não há religião sem liberdade. Não há liberdade sem religião. "O despotismo é que passará sem a fé: a liberdade não passa", dizia TOCQUEVILLE, edificado pelo espetáculo dos Estados Unidos. (BARBOSA, [1903], 1981, p. 26-27). 
Na Constituição de 1891, no art. 72, afirma-se, no $\S 3^{\circ}$. que "Todos os individuos e confissões religiosas podem exercer publica e livremente o seu culto, associando-se para esse fim, adquirindo bens, observadas as disposições do direito comum”. Diz, a seguir, que o Estado só reconhece o casamento civil $\left(\S 4^{\circ}\right)$, assim como os cemitérios são considerados seculares e públicos, sendo permitidos os ritos e cultos de cada religião, desde que não sejam ofensivos à "moral pública e as leis" (§ $\left.5^{\circ}\right)$. E no $\S 7^{0}$ define que "Nenhum culto ou igreja gozará de subvenção official, nem terá relações de dependencia, ou alliança com o Governo da União, ou o dos Estados” (BRASIL, 1891).

Este art. n. 72 da Constituição de 1891 define os direitos e as garantias fundamentais. Dentre esses direitos e garantias deve-se destacar um importante parágrafo para a análise deste artigo: o seu $\S 6^{\circ}$ que diz "Será leigo o ensino ministrados nos estabelecimentos públicos” (BRASIL, 1891). Começa-se, aqui, a laicização do ensino das escolas públicas brasileiras, mas não sem um longo conflito. A Constituição de 1891, porém, não impedirá, apesar de não dizer explicitamente, “a existência de uma rede privada de ensino fora da regulamentação oficial” (CURY, 2005, p. 77).

Essa laicização, que teve início com a República, não foi concebida numa modalidade que rechaça a religião, como Cury destaca: há "a determinação de uma posição não religiosa da escola pública”, mas disso "não se deve deduzir qualquer tipo de defesa da irreligião" (CURY, 2005, p. 78), como se percebeu anteriormente no Discurso de Rui Barbosa de 1903.

A laicidade foi um processo de autonomização da esfera pública da influência religiosa, particularmente da Igreja Católica. Ela começa a se estruturar a partir de longa influência, que passa pelo Humanismo renascentista, a Reforma Protestante, a Ilustração, a Declaração dos Direitos do Homem, a Declaração de Independência e a Constituição Americana, a Revolução Francesa, dentre outras expressões, e por diversos pensadores como John Locke, Voltaire, Rousseau, Montesquieu, Kant, e tantos outros. 
Certamente, a marca francesa foi muito significativa, desde Condorcet, em 1791, que dizia que "é rigorosamente necessário separar da moral os princípios de todas as religiões particulares e de não admitir na instrução pública o ensino de qualquer culto religioso" (CONDORCET, 1989, p. 18-19). ${ }^{10}$ Outra figura significativa, já referida, foi Jules Ferry, que cria a "escola laica” em 1879 e que "envidará todos os esforços para 'arrancar as crianças da influência da igreja'.” (DOMINGOS, 2008, p. 156). ${ }^{11}$

A reação Católica não tardou. Na realidade, a Igreja Católica já estava contrariada desde a ingerência inglesa e protestante em 1810, como se verificou na Constituição de 1824. A afirmação de uma Igreja "romana” e não nacional vai sendo pensada e se tornando mais clara e efetiva a partir do $2^{\circ}$ Reinado (1840). Essa tendência seguirá as orientações de Roma contra o que a Igreja Católica sofria na Europa depois da Revolução Francesa e das ideias liberais. O cume dessa posição aparece com o papa Pio IX e seu Syllabus Errorum, promulgado 1864, com as 80 teses contra a modernidade. E, logo depois, com o Concílio Vaticano I (1869-1870), a declaração da infalibilidade papal (1870) e a orientação contra a interferência dos governos na Igreja (regalismo), que se efetivou com a posição ultramontana (além das montanhas, além dos Alpes), ou seja, a afirmação da autoridade do Pontífice contra o liberalismo, o protestantismo, a maçonaria, assim como o socialismo e as ideias seculares (SANTIROCHHI, 2010, p. 24).

No Brasil, tal conflitividade se revelará na “Questão Religiosa” (1872 e 1875), que desnuda o grau de problemas desencadeados pelo ultramontanismo e a reação católica. Dom Macedo Costa (Pará) e Dom Vital (Olinda) protagonizaram um embate com a Maçonaria, chegando à ameaça de ex-comunhão aos seus membros, além da proibição de sepultamento em cemitérios, que eram religiosos, e da sua expulsão das Irmandades (Dom Vital). O problema chegou ao Imperador Dom Pedro II, que tinha jurisdição em relação às Irmandades, e o Conselho de Ministros determinou a prisão dos bispos. A Questão se resolveu com um acordo entre Dom Pedro II e o Papa Pio IX: a anistia aos bispos e a suspensão da expulsão dos maçons das Irmandades.

\footnotetext{
${ }^{10}$ Il était donc rigoureusement nécessaire de séparer de la morale les principes de toute religion particulière, et de n'admettre dans l'instruction publique l'enseignement d'aucun. [Trad. dos autores].

${ }^{11} \mathrm{O}$ Ensino Religioso não faz parte do currículo na França, mas desde a promulgação da lei de 28 de março de 1882 , de J. Ferry, que tornou o Ensino Primário obrigatório - isso influenciou a visão educacional no Brasil -, "as escolas públicas primárias possuem um dia livre durante a semana 'além do domingo', para 'permitir aos pais, se eles desejarem, fazer ministrar a instrução escolar fora dos estabelecimentos escolares'. Ainda hoje, as escolas primárias não ministram aulas nas quartas-feiras, dia acordado desde essa época entre Igreja e Estado, para a catequese." (DOMINGOS, 2008, p. 155).
} 
Essa dinâmica, que emerge na segunda metade do século XIX, produzirá no Brasil um processo de "romanização" da Igreja, que se dará pela definição de uma posição política tradicional da Igreja, assegurando seus direitos diante do avanço do positivismo e das ideias liberais. E, principalmente, pela entrada de muitas congregações religiosas europeias, que virão com objetivos claros de assumirem o trabalho missionário, atuando com as práticas devocionais. É o caso dos Redentoristas, que chegaram em 1894 para se responsabilizarem pela devoção de N. S. Aparecida. Mas também houve outra opção fundamental, com resultados que viriam nas primeiras décadas do século XX: a Igreja enfrentará o novo Estado republicano investindo no trabalho com as famílias e a educação.

Diversas congregações religiosas chegaram ao Brasil e abriram seus colégios e escolas no país nesse momento, como os Irmãos Maristas, que desembarcaram no Brasil em 1897, atendendo a pedido de Dom Silvério Gomes Pimenta, Bispo de Mariana, para cuidarem de um colégio em Congonhas do Campo (Minas Gerais). Para se ter uma noção desse "investimento", na década de 1890 entraram 14 congregações, na década seguinte (1900) foram 20 e nas décadas de 1910 e 1920 foram, respectivamente, 23 e 41 instituições religiosas católicas (BITTENCOURT, 2017, p. 38). Congregações que já estavam no Brasil, como os Lazaristas e seu importante Colégio do Caraça, em Minas Gerais, que formou gerações da elite brasileira como os presidentes Antonio Carlos e Arthur Bernardes, ampliaram sua presença, assim como os Maristas, Verbitas, Salesianos e muitas Ordens Femininas.

Consolida-se, assim, a ocupação de um espaço confessional importante da Igreja nas escolas. Formará quadros de dirigentes que serão importantes nas décadas iniciais do século XX até obter grandes conquistas nos governos, por exemplo, de Getúlio Vargas, um agnóstico. Destaca-se a autorização para o Ensino Religioso, de frequência facultativa, a partir de 1931, com o Decreto n. 19.941, de 30 de abril, que dispõe sobre a instrução religiosa nos diversos segmentos escolares, primário, secundário e normal. (BRASIL, 1931). Momento também da criação da Liga Eleitoral Católica - LEC, da inauguração em 12 de outubro de 1931, dia de N.S. Aparecida, da estátua do Cristo Redentor no Rio de Janeiro. Logo depois, na Constituição de 1934, haveria a criação das capelanias militares, de assistência às expedições militares, sem ônus aos cofres públicos, exigindo-se que os capelães fossem sacerdotes natos. Portanto, os frutos do enfrentamento foram enormes para a Igreja Católica. 
Mas o processo de volta do "ensino de religião" nas escolas públicas no Brasil, já começara bem antes disso, em Minas Gerais, desde seu Congresso Constituinte de 1906. Na década de 1910 havia um longo debate sobre isso e, nesse ano, houve o $1^{\mathrm{o}}$ Congresso Católico Mineiro, em Juiz de Fora, com representação de trezentas e uma associações religiosas, que aprovou o "estabelecimento de cursos de filosofia e moral", uma forma de "resgatar o ensino religioso através da filosofia" (SILVA, 2013, p. 70). O $2^{\circ}$ Congresso (1911), em Belo Horizonte, define que "É conveniente que os católicos aproveitem enquanto ela durar, a tolerância oficial, para promover o ensino religioso nas escolas públicas" (A BÚSSOLA, 1911, p. 1 apud SILVA, 2013, p. 71). E o $4^{\circ}$. Congresso, em 1918, propõe a criação de uma associação "vasta e poderosa" do Ensino Religioso (SILVA, 2013, p. 72). Esse trabalho de resistência propiciará que em 1925, com o governador Antônio Carlos Ribeiro de Andrada, Minas seja o primeiro estado a colocar o "ensino de religião nas escolas públicas".

A defesa do Ensino Religioso encontrará guarida, logo depois, no Congresso Catequético de 1928 (3 a 7 de setembro), em Belo Horizonte. E Dom Antonio dos Santos Cabral, primeiro bispo de Belo Horizonte, fará duras críticas à República, dizendo em seu discurso de abertura sobre os "39 anos de república agnóstica" e de "gerações descatolizadas". E terá apoio papal, que pode ser observado na mensagem enviada pelo Papa Pio XI: "O laicismo nas escolas é um atentado à liberdade de consciência. Não se podem trancar as escolas à religião inspiradora de bons governos." (SILVA, 2007, p. 32).

E é nesse contexto que em 1932 os Pioneiros da Educação - Anísio Teixeira, Lourenço Filho, Afrânio Peixoto, Cecília Meireles, Fernando de Azevedo, dentre outros - lançarão seu Manifesto em favor de uma educação pública, aberta a todos, sem discriminação. E o embate entre católicos e liberais, entre confessionalidade e laicidade teria ainda longa continuidade. Os católicos representando "grupos oligarcas" e autoritários, conservadores, e os liberais, como os Pioneiros da Educação, os "setores progressistas" das novas classes da elite emergente. Esqueceu-se, contudo, da maioria da população, e ainda longe estava "o nascimento da "escola do povo" (CURY, 1986, p. 189), de uma educação popular, inclusiva, libertadora e decolonial. 


\section{A situação atual do Ensino Religioso}

Ao se discutir o tema do Ensino Religioso no Brasil deve-se considerar, de antemão, os aspectos filosóficos, jurídicos e políticos nos quais esse ensino esteve inserido, nas sucessivas fases de sua legalização, seja como ensino de religião, seja como disciplina obrigatória no currículo, mas facultativa aos alunos. Há o pressuposto que o texto da lei buscou se adequar às demais liberdades públicas, dentre elas a liberdade de culto religioso e a laicidade do Estado.

Vale salientar que o pospor-se da Primeira Constituição Republicana, de 1891, ao art. 72, § 6, como já apresentado, afirmava que "Será leigo o ensino ministrado nos estabelecimentos públicos" (BRASIL, 1891), já sinalizava por críticas:

silêncio da Constituição, é incontestável que a liberdade do ensino como consequência da liberdade individual deve enumerar-se entre os direitos do cidadão de um Estado livre. Se a Constituição declara a liberdade de indivíduo, da consciência religiosa, da manifestação do pensamento, deve admitir como consequência a liberdade de ensino. A liberdade de ensino é uma consequência da liberdade de consciência. Por isso, é leigo o ensino ministrado nos estabelecimentos públicos. [...] $\mathrm{O}$ respeito à liberdade de consciência, à igualdade incontestada dos cidadãos diante da lei do Estado, seja qual for sua crença religiosa, tem motivado a árdua e difícil questão acerca do ensino religioso nas escolas. Uns queriam que o ensino fosse inteiramente separado da religião e outros que a religião acompanhasse o ensino, unindo a educação à instrução. Daí as duas escolas que a respeito se formaram: a religiosa ou confessional e a leiga. (SCAMPINI, 1978, p. 116s).

Partindo dessa posição de Scampini, pode-se intuir que as concepções do ensino leigo provavelmente foram inspiradas em ideais republicanos, com forte influência norte-americana, mas a concretização se tornou expressiva no texto da lei e definiu a natureza do Ensino Religioso.

Neste aspecto, é possível afirmar que desde a década de 1930, e nas Constituições sucessivas de 1946, 1967, 1969 e 1988, homologou-se a dupla garantia legal. Em primeira instância, garantiu-se a permanência e a oferta da disciplina no espaço escolar, e em segunda instância, assegurou a liberdade de fazer ou não a matrícula na disciplina, afirmando que a plena liberdade religiosa também se constitui em dizer não. E essa compreensão perdurará até os dias atuais. 
Porém, foi a Constituição de 1934 que inovou ao atribuir à União Federal a tarefa de fixar as diretrizes da educação nacional. Ao criar o Conselho Federal de Educação ${ }^{12}$, deu aos Estados e ao Distrito Federal a autonomia para organizar seus sistemas de ensino, e ainda, instalar Conselhos Estaduais de Educação com funções idênticas às do Conselho Federal, evidentemente, no âmbito de suas respectivas jurisdições.

Estimulado pela necessidade de diretrizes nacionais de educação, esse momento torna-se único na história educacional do Brasil. Assiste-se a um conjunto de reformas, promulgadas entre 1942 e 1946, as chamadas "leis orgânicas de ensino", por Gustavo Capanema, Ministro da Educação do Estado Novo. Efetivamente, é com a queda desse Estado Novo, e a elaboração de mais uma Constituição, que estará definida a competência da União em legislar sobre "diretrizes e bases da educação nacional". 13

E nas três Leis de Diretrizes e Bases da Educação Nacional (Lei n. 4.024/61, 5.692/71 e 9.394/96), o Ensino Religioso é contemplado com sua inclusão no sistema escolar, o que não deixou de produzir inúmeros debates e posicionamentos de grupos favoráveis e contrários a essa presença do componente curricular em escolas da rede oficial de ensino.

A Lei de Diretrizes e Bases da Educação Nacional de n. 9.394/96 (BRASIL, 1996), que foi precedida por uma mobilização nacional, com desfecho na sua publicação em 20 de dezembro de 1996, incluiu o ensino religioso no currículo escolar, através do art. 33. Sua redação reativou a polêmica entre favoráveis e contrários à sua permanência no sistema escolar, tanto na normalidade dos demais componentes curriculares quanto pelos elementos presentes no texto, considerados empecilhos à sua operacionalização nessa normalidade. Na realidade, não se

\footnotetext{
${ }^{12}$ O Conselho Federal de Educação foi extinto pela Lei 9.131, de 24/11/1995, ao mesmo tempo em que se instituiu o Conselho Nacional de Educação, que passou a ser composto por duas câmaras autônomas: a Câmara de Educação Superior e a Câmara de Educação Básica. Esta última, na sua função deliberativa, como parte de um Conselho Nacional de Educação, estabelece as normas mínimas para o cumprimento do que determina a Lei de Diretrizes e Bases da Educação Nacional, no que se refere ao Ensino Fundamental.

${ }^{13}$ Carneiro (1998, p. 23) diz: "os termos diretrizes e bases como conceitos integrados não surgiram na educação brasileira de forma refletida, ou seja, em decorrência de uma filosofia da educação que, nutrida por uma crítica pedagógica coerente, desaguasse numa postura de confrontação à visão fragmentária de compreensão de educação, de sistema educacional e de seus desdobramentos. São conceitos que vão se encorpando." Na Constituição Federal de 1934, o artigo 5으, inciso XIV, apresenta como competência da União "traçar as diretrizes da Educação Nacional" (BRASIL, 1934). Com a Constituição do Estado Novo (1937), reforçou-se a ideia das diretrizes, pela adição do conceito bases. Dizia o artigo 15 , inciso IX, que à União incumbia "fixar as bases e determinar os quadros da educação nacional, traçando diretrizes às quais devem obedecer a formação física, intelectual e moral da infância e da juventude." (BRASIL, 1937). Já na Constituição de 1946, artigo 5oa alínea d, definem-se "diretrizes e bases da educação nacional" (BRASIL, 1946).
} 
percebeu nenhuma inovação com o referido artigo 33, mas a presença de elementos oriundos de legislações passadas, que agravaram ainda mais as dificuldades para a sua aplicação nas escolas da rede pública oficial, quando menciona a opção pela modalidade confessional e/ou interconfessional, além da questão de colocar o ER "sem” ônus para os cofres públicos.

A mobilização nacional foi mantida, em nova etapa, por defensores da área, incluindo educadores e representantes de diversas denominações religiosas, manifestando insatisfação quanto à redação dada ao artigo 33 da referida LDB. O movimento resultou na sanção da Lei n. 9.475/97, que deu nova redação ao artigo 33, sendo a primeira alteração da LDB. Não se pode deixar de mencionar o papel de lideranças políticas como o deputado Padre Roque Zimmermann (PT), a articulação do Fórum Nacional Permanente do Ensino Religioso - FONAPER e até mesmo da Conferência Nacional dos Bispos do Brasil - CNBB. ${ }^{14}$

A Lei de Diretrizes e Bases da Educação Nacional n. 9.394/96, com a alteração do seu artigo 33, através da Lei n. 9.475/97, deu novo caráter ao ER, quando diz que ele "é parte integrante da formação básica do cidadão e constitui disciplina dos horários normais das escolas públicas de ensino fundamental, assegurado o respeito à diversidade cultural religiosa do Brasil, vedadas quaisquer formas de proselitismo” (BRASIL, 1997). Mas isso não resolveu a problemática do Ensino Religioso no Brasil.

A implementação da legislação foi fundamentada por pareceres e regulamentada por resoluções que, no caso das mais recentes, reconheceram o Ensino Religioso como a quinta área de conhecimento e como componente curricular (BRASIL, 2010a, Resolução CNE/CEB n. 7/2010). Embora se reconheça esse processo como importante avanço, a normalização da área, no conjunto curricular da escola, não fez com que esses avanços fossem galgados na definição de sua natureza.

A problemática centenária, como já exposto, envolve discussões da laicidade do Estado e da liberdade religiosa do cidadão, e sempre faltaram bons fundamentos nos debates, de ambos os lados. E a situação ainda se tornará mais complexa quando é assinado o Acordo entre o Brasil e a Santa Sé, em 13 de novembro de 2008, que

\footnotetext{
${ }^{14}$ Detalhes do processo de regulamentação da Lei $9.475 / 97$, que deu nova redação ao artigo 33 , são encontrados em muitas pesquisas sobre o tema, cabe destacar a pesquisa de doutorado de Siqueira (2012). Deve-se observar que a participação da CNBB se caracterizou pela defesa de um Ensino Religioso Escolar não confessional, inclusive a posição do Padre Roque Zimmermann, do Partido dos Trabalhadores PT.
} 
entrou em vigor pelo Decreto n. 7.107, publicado no Diário Oficial da União em 12 de fevereiro de 2010 (BRASIL, 2010b). Consolidou-se a situação e a atuação da Igreja Católica no Brasil e o seu estatuto jurídico. Desta forma, além da liberdade para a realização de seus trabalhos pastorais, reconheceu os títulos de estudo, autorizou o Ensino Religioso nas escolas públicas, validou o casamento religioso e as sentenças eclesiásticas acerca do matrimônio, além de definir questões fiscais de interesse da instituição eclesiástica, dentre outras questões em seus 20 artigos.

O ponto mais delicado do referido tratado jurídico foi, sem dúvida, o artigo que garante o Ensino Religioso nas escolas da rede pública, o qual merece destaque por suas implicações sociopolíticas e culturais na sociedade brasileira, inclusive para setores da própria Igreja, como o Setor do Ensino Religioso da CNBB, contrário ao Acordo. $\mathrm{O}$ art. $11 \mathrm{diz}$ :

A República Federativa do Brasil, em observância ao direito de liberdade religiosa, da diversidade cultural e da pluralidade confessional do País, respeita a importância do ensino religioso em vista da formação integral da pessoa.

$\S 1^{\circ}$. O ensino religioso, católico e de outras confissões religiosas, de matrícula facultativa, constitui disciplina dos horários normais das escolas públicas de ensino fundamental, assegurado o respeito à diversidade cultural religiosa do Brasil, em conformidade com a Constituição e as outras leis vigentes, sem qualquer forma de discriminação. (BRASIL, 2010b).

Com certeza, o parágrafo $1^{\circ}$ do Art. 11, "católico e de outras confissões religiosas" acarretou novas discussões sobre a natureza do Ensino Religioso: confessional ou não confessional. E o debate público não tardou, inflamou com razão os meios intelectuais, educacionais, políticos e religiosos, especialmente dos docentes de ER. E, como consequências, podemos elencar duas ações que demonstraram o ressurgir com mais energia das polarizações:

a) a bancada "evangélica" levou a cabo sua reivindicação sobre a Lei Geral das Religiões, de autoria do deputado George Hilton (PP-MG), pelo Projeto de Lei 5.598/o9 para regulamentar o direito constitucional de livre exercício de crença e cultos religiosos, que teve origem no Projeto de Lei n. 160/2009, na Câmara Federal;

b) e a procuradora-geral da República, em 2010, Deborah Macedo Duprat de Britto Pereira, através da Ação Direta de Inconstitucionalidade n. 4.439, solicitou ao Supremo Tribunal Federal que realizasse uma interpretação do 
artigo 33 da Lei n⿳0 9.393/96, conforme a Constituição Federal, determinando que o Ensino Religioso nas escolas públicas fosse apenas de natureza nãoconfessional, proibindo professores representantes de tradições religiosas, bem como interprete o artigo 11, $\S 1^{0}$, do Acordo entre Brasil e Santa Sé, relativo ao Estatuto Jurídico da Igreja Católica no Brasil, de maneira a assegurar que o Ensino Religioso nas escolas públicas fosse de natureza nãoconfessional; ou, caso se entenda por incabível este último pedido, que o STF declare a inconstitucionalidade do trecho "católico e de outras confissões religiosas", constante no $\S 1^{\mathrm{o}}$ do artigo 11 do referido Tratado. (BRASIL, 2010b).

A Lei Geral das Religiões, segundo os registros encontrados no Senado Federal, pelo Projeto de Lei da Câmara n. 160, de 2009 e o n. 5.589/2009, foi arquivada definitivamente, nos termos do $\S 2^{\circ}$ do art. 332 do Regimento Interno, em 27 de dezembro de 2018.

E a Ação Direta de Inconstitucionalidade n. 4.439 teve muitos desdobramentos, durante sete anos, dentre os quais se destaca a Audiência Pública, que ocorreu em 15 de junho de 2015, convocada pelo Ministro Luís Roberto Barroso, com a participação de 31 representantes de entidades religiosas e/ou educacionais. Cada expositor recebeu a orientação para apresentar seus argumentos sobre o tema em 15 minutos, com a audiência transmitida ao vivo e, posteriormente, os posicionamentos foram disponibilizados no canal do Supremo Tribunal Federal, no YouTube. Ao encerrar as apresentações, o ministro ressaltou o enriquecimento intelectual que foi proporcionado a todos, dando voz a posições divergentes que representavam o próprio debate da sociedade brasileira.

Em 27 de setembro de 2017, em sessão plenária, os ministros do STF julgaram improcedente a Ação Direita de Inconstitucionalidade n. 4.439. Pela maioria dos votos ( 6 X 5) os ministros acompanharam o relator, Ministro Alexandre de Moraes, e entenderam que há "constitucionalidade dos artigos 33 , caput e $\S \S 1^{\circ}$ e $2^{\circ}$, da Lei 9.394/1996, e do art. 11, § $1^{\circ}$, do Acordo entre o Governo da República Federativa do Brasil e a Santa Sé", e ainda afirmaram a "constitucionalidade do ensino religioso confessional como disciplina facultativa dos horários normais das escolas” (STF, 2017). A análise dos pareceres e, mais ainda, dos pronunciamentos dos ministros 
mostram as contradições, a falta de fundamentação dos argumentos, a desinformação e o desconhecimento que se tinha sobre a situação do Ensino Religioso, que propiciaram votos tão desconexos ao considerarem essa constitucionalidade. Como juridicamente puderam conciliar o art. 33 da Lei 9.394/96, que afirma a não confessionalidade, o não proselitismo, com o art. 11 da Lei n.7.107/2010, claramente privilegiando "o ensino religioso, católico e de outras religiões”? Esse ainda será tema para diversas análises e hermenêuticas jurídicas.

Nesse contexto sobre a (in)constitucionalidade do Ensino Religioso, de natureza confessional e não confessional, também estiveram em pauta outras discussões versando sobre o Ensino Religioso, interligadas com o mesmo tema, mas com outras especificidades próprias: a questão curricular e a formação docente.

A elaboração da Base Nacional Comum Curricular - BNCC ocasionou outro momento para o embate. Em sua primeira versão do documento, disponibilizada publicamente em setembro de 2015, o Ensino Religioso aparece como componente curricular, dentro da área de Ciências Humanas. Essa novidade positiva para o Ensino Religioso agregou novas disputas epistemológicas no campo das Ciências Humanas. Consequentemente, na segunda versão, o Ensino Religioso foi retirado da área de Ciências Humanas e colocado como área própria, seguindo a Resolução CNE/CEB n. 07/2010. Isso provocou discussões em torno da formação e profissionalização docente para o Ensino Religioso, já concebida e ancorada desde 2006 na área de Ciências da Religião. ${ }^{15}$

As avaliações iniciais realizadas no X Seminário Nacional de Formação de Professores para o Ensino Religioso - SEFOPER, realizado em Taguatinga (DF) em novembro de 2008, mostraram a importância de se retomar a discussão sobre as Diretrizes Curriculares Nacionais - DCN. Em 1997, o FONAPER havia produzido os Parâmetros Curriculares Nacionais do Ensino Religioso - PCNER, que praticamente nasceram junto com essa entidade (1995). O Fórum já havia enviado ao Ministério da Educação - MEC proposições de DCNs em 1998, 2004 e, agora, a que se discutiu em Taguatinga, em 2008. E não obteve respostas. E num movimento mais objetivo e

\footnotetext{
${ }^{15}$ Tal debate, apesar de ter surgido na UFJF em 1969 (PIEPER, 2018, p. 235), aconteceu no IX Seminário de Capacitação Docente para o Ensino Religioso, co-promovido pelo FONAPER e PUC-SP, com apoio da SOTER, nos dias 03 e 04 de outubro de 2006 . Fruto dessa discussão foi o livro “Ensino Religioso e formação docente: ciências da religião e ensino religioso em diálogo" (SENA, 2006).
} 
prático, criou-se a Rede Nacional de Licenciaturas de Ensino Religioso - RELER, em 2012, num trabalho articulado de universidades e de colaboradores de vários estados que integravam já 15 cursos, dois deles reconhecidos em universidades federais: UFPB e UFJF. E nos Seminários subsequentes da RELER as questões das futuras DCNs nunca deixaram de ser tematizadas.

A homologação da BNCC, com o componente curricular Ensino Religioso, em dezembro de 2017, abriu caminho para a discussão das Diretrizes. Em março de 2018, o CNE cria uma comissão, através da Portaria CNE/CES n. 3, de $1^{\circ}$ de março de 2018, para "analisar a necessidade de se estabelecer Diretrizes Curriculares Nacionais de curso de graduação em Ciências da Religião" (BRASIL, 2018a), que seria o curso que o consenso da área havia definido (2006) como aquele que formaria o docente de Ensino Religioso.

Encaminhadas as propostas da Comissão ao Conselho Nacional de Educação e acolhidas por seu presidente, professor Gilberto Gonçalves Garcia, foi nomeado como relator o professor Ivan Claudio Pereira Siqueira. Iniciou-se os trabalhos de elaboração e discussão das Diretrizes Curriculares para os cursos de licenciatura em Ciências da Religião. O Parecer CNE/CP n. 12/2018, foi aprovado, na sessão de 02 de outubro de 2018, com apenas um voto contrário, da Conselheira Márcia Angela da Silva Aguiar, que justificou sua posição da seguinte forma: por "entender que tal iniciativa poderá contribuir para introduzir nas IES e no interior das escolas públicas conflitos religiosos existentes (e exacerbados na atual conjuntura política) na sociedade brasileira" (BRASIL, 2018b, p. 14).

O CNE realizou audiência pública em 18 de setembro de 2018, em sua sede, para aprimoramento do texto do Parecer. Em 28 de dezembro de 2018 houve a aprovação da Resolução n. 5, de 28 de dezembro de 2018, que instituiu as Diretrizes Curriculares Nacionais para o curso de licenciatura em Ciências da Religião. No Parecer $\mathrm{CNE} / \mathrm{CP}$ n. 12/2018 fica estabelecido que: "o estudo qualificado dos conhecimentos religiosos possibilitará a construção de saberes especializados que subsidiarão o futuro exercício da docência em Ensino Religioso por meio de fundamentação científica própria das Ciências da Religião” (BRASIL, 2018b, p.10). 
Em todos os documentos recentes nos quais constam o Ensino Religioso, seja na BNCC ou nas Diretrizes Curriculares para os cursos de licenciatura em Ciências da Religião, o objeto de estudo definido é o(s) conhecimento(s) religioso(s).

Mas há um detalhe que precisa ser mencionado: na terceira versão apresentada, publicada em abril de 2017, a área de conhecimento e o componente curricular do Ensino Religioso deixaram de ser incluídas. Após consultas e audiências públicas promovidas pelo CNE em todas as regiões do país, o alto percentual de solicitações para a reinserção do Ensino Religioso na BNCC contribuiu para que na versão final ele estivesse presente, como área de conhecimento independente e como componente curricular no ensino fundamental.

Todavia, a saga do Ensino Religioso não terminou com sua a reinserção no texto da BNCC. A homologação da BNCC foi efetivada pela Portaria n. 1.570, de 20 de dezembro de 2017 e mostrou que o embate não havia desaparecido. Praticamente, colocou uma condicionante:

Art. $2^{\circ}$ Após a publicação do Acórdão do Supremo Tribunal Federal no julgamento da Ação Direta de Inconstitucionalidade $n^{\circ} 4439$, o Ministério da Educação poderá solicitar ao Conselho Nacional de Educação reavaliação do disposto para o ensino religioso na BNCC. (BRASIL, 2017, p. 146).

O Acordão sobre a decisão do STF a respeito da ADI n. 4439/2010, de 27 de setembro de 2017, foi divulgado em 22 de junho de 2018. E mesmo com a posição favorável ao ER Confessional, o CNE não alterou a BNCC e, pelo contrário, deu sequência às discussões sobre a criação das DCNs de Ciências da Religião, homologadas em dezembro de 2018. E a BNCC, definindo o ER como não confessional, explicita que o objeto do ER são os conhecimentos religiosos e as suas Unidades Temáticas mostram claramente essa posição não confessional: Identidades e Alteridades, Manifestações Religiosas, Crenças Religiosas e Filosofias de Vida. E cada Unidade Temática abre um leque de possibilidades de investigação da cultura religiosa, dos fenômenos de crença e não crença, de forma inclusiva, na perspectiva da área de Ciências da Religião. Os objetivos do ER na BNCC demonstram o alinhamento com laicidade do Estado: 
a) proporcionar a aprendizagem dos conhecimentos religiosos, culturais e estéticos, a partir das manifestações religiosas percebidas na realidade dos educandos;

b) propiciar conhecimentos sobre o direito à liberdade de consciência e de crença, no constante propósito de promoção dos direitos humanos;

c) desenvolver competências e habilidades que contribuam para o diálogo entre perspectivas religiosas e seculares de vida, exercitando o respeito à liberdade de concepções e o pluralismo de ideias, de acordo com a Constituição Federal;

d) contribuir para que os educandos construam seus sentidos pessoais de vida a partir de valores, princípios éticos e da cidadania. (BRASIL, 2017, p. 434).

Como se verifica nesses objetivos, o ER tem todas as condições de propiciar momentos importantes na formação e na educação das crianças, adolescentes e jovens da Educação Básica. O ponto de partida é a "realidade dos educandos" e a "liberdade de consciência e de crença", portanto sem impor, doutrinar e manipular. Quer, ao contrário, promover os direitos humanos, o diálogo entre quem crê e quem não tem fé, condição fundamental para uma sociedade democrática, laica, que respeita, acolhe e estuda a diversidade religiosa, o pluralismo de ideias e variadas formas e maneiras de ser e viver. Mas além de tudo isso, e talvez esse seja um objetivo fundamental, quer colaborar para que os educandos, mais do que "conhecimentos religiosos", tenham e construam com qualidade seus sentidos de vida, de forma ética e cidadã. Nessa perspectiva, o ER não é ameaça à laicidade, mas a sua explicitação.

Ao final de 2019, atendendo ao que estava disposto no art. 23, da Res. CNE/CP n. 02/2017 (BRASIL, 2017), que apresentava o problema se o Ensino Religioso teria "tratamento como área do conhecimento" ou como componente integrado às Ciências Humanas, o CNE decidiu por unanimidade que ele "passe a ser componente curricular da área de Ciências Humanas, no Ensino Fundamental.” (Parecer CNE/CEB n. 8/2019, BRASIL, 2019). Tal decisão do CNE/CEB de 19 de dezembro de 2019, foi publicada no DOU n. 246, em 20 de dezembro de 2019. Com essa decisão, o Ensino Religioso se integra totalmente na dinâmica educacional e à BNCC, particularmente com as Ciências Humanas, retirando o que causava certo incômodo por ser tratado como uma área própria, desde a Res. CNE/CEB n. 7/2010.

\section{Conclusão}

O debate sobre a presença do Ensino Religioso na Escola Pública não terminou e nem terminará tão cedo. A caminhada desse componente curricular no Brasil é 
inédita. Não há outro país que fez e nem tenha produzido o que foi e está sendo construído aqui. E um marco desse processo, verdadeira mudança de paradigma na história da educação, foi a distinção que W. Gruem fez no início da década de 1970 entre Ensino Religioso e Catequese. O primeiro com o objeto da religiosidade, enquanto categoria antropológica que nos leva à busca de sentidos para viver, e o segundo, a catequese, evidentemente confessional, como educação da fé. (GRUEN, 1974). No fundo, estava a motivação de Gruen, inspirada em Paulo Freire (SIQUEIRA et al, 2018, p. 660), para um ensino promotor de liberdade, de uma "educação como prática da liberdade”. Nesse sentido, ainda é um grande desafio pensar numa educação popular, realmente inclusiva dos segmentos da sociedade excluídos e das camadas da população alijadas de seus direitos básicos da cidadania. E o ER pode contribuir muito para isso.

No espaço de um artigo não foi possível recuperar todos os antecedentes históricos e nem os termos do longo debate filosófico e jurídico sobre a laicidade e a confessionalidade, mas foi possível apresentar certo panorama desse debate sobre o Ensino Religioso no país. Pode-se dizer, ao se concluir, que a caminhada do ER no Brasil, que tem sido referência para muitos outros países como Chile e Costa Rica, é exitosa e revela que é possível realizar um trabalho que possa incluir todos os educandos e criar tempo e espaço de diálogo.

A conquista da inclusão do ER na BNCC e a criação das DCNs para a formação inicial de professores, a despeito de todos os problemas históricos que a área reconhece, como precariedade teórica, didática, escolar, o desafio da formação continuada, dentre outros, não tira o mérito da produção de uma proposta curricular que poderá ser aperfeiçoada, mas que oferece muitos elementos educativos, capazes de propiciar um diálogo inter e transdisciplinar.

\section{REFERÊNCIAS}

BAPTISTA, Paulo Agostinho N. Ciências da Religião e Ensino Religioso: o desafio histórico da formação docente de uma área de conhecimento. REVER: revista de estudos da religião, São Paulo, v. 15, n. 2, p. 107-125, dez. 2015. Disponível em:

https://revistas.pucsp.br/rever/article/view/26189. Acesso em: 22 maio 2019.

BARBOSA, Rui. Discurso no Colégio Anchieta. Palavras à Juventude. 19 jul. 1903. Rio de Janeiro: Fundação Casa Rui Barbosa, 1981. Disponível em:

https://sites.icmc.usp.br/andcarva/rb.pdf. Acesso em: 21 maio 2019. 
BARBOSA, Rui. Reforma do ensino primário e várias instituições complementares da instrução pública - 1883. In: BARBOSA, Rui. Obras completas de Rui Barbosa, v. 10, tomo I, II, III, IV. Rio de Janeiro: Ministério da Educação e Saúde, 1947.

BASTOS, Maria Helena Camara Bastos. Método intuitivo e lições de coisas por Ferdinand Buisson. História e Educação (online). Porto Alegre, v. 17, n. 39, p. 231-253, jan./abr. 2013. Disponível em: https://www.scielo.br/scielo.php?script=sci_arttext\&pid=S223634592013000100013. Acesso em: 26 maio 2019.

BAUBÉROUT, Jean; MILOT, Micheline. Laïcités sans frontières. Paris: Seuil, 2011.

BITTENCOURT, Agueda Bernardete. A era das congregações - pensamento social, educação e catolicismo. Pro-Posições, Campinas, v. 28, n. 3, p. 29-59, dez. 2017. Disponível em: http://www.scielo.br/scielo.php?script=sci_arttext\&pid=So10373072017000300029\&lng=pt\&nrm=iso. Acesso em: 25 maio 2019.

BRASIL. Conselho Nacional de Educação - Câmara de Educação Básica. Parecer n. o8/2019, de 19 de dezembro de 2019. Disponível em: https://pesquisa.in.gov.br/imprensa/jsp/visualiza/index.jsp?data=20/12/2019\&jornal=515 \&pagina=142\&totalArquivos=289. Acesso em: 25 maio 2020.

\section{BRASIL. Constituição da República dos Estados Unidos do Brasil, de 16 de julho de 1934. Disponível em: \\ http://www.planalto.gov.br/ccivil_03/constituicao/constituicao34.htm. Acesso em: 13 nov. 2019.}

BRASIL. Constituição dos Estados Unidos do Brasil, de 16 de novembro de 1937. Disponível em: http://www.planalto.gov.br/ccivil_03/Constituicao/Constituicao37.htm. Acesso em: 13 nov. 2019.

BRASIL. Constituição dos Estados Unidos do Brasil, de 16 de setembro de 1946. Disponível em: http://www.planalto.gov.br/ccivil_03/constituicao/constituicao46.htm. Acesso em: 13 nov. 2019.

BRASIL. Constituição dos Estados Unidos do Brasil, de 24 de fevereiro de 1891. Disponível em: http://www.planalto.gov.br/ccivil_03/Constituicao/Constituicao91.htm. Acesso em: 01 maio 2019.

BRASIL. Decreto n. 119A, de 07 de janeiro de 1890. Disponível em: http://www.planalto.gov.br/ccivil_o3/decreto/1851-1899/D119-A.htm. Acesso em: 15 fev. 2019.

BRASIL. Decreto n. 19.941, de 30 de abril de 1931. Disponível em: https://www2.camara.leg.br/legin/fed/decret/1930-1939/decreto-19941-30-abril-1931518529-publicacaooriginal-1-pe.html. Acesso em: 21 maio 2019.

BRASIL. Decreto n. 2006, de 24 de outubro de 1857. Approva o Regulamento para os collegios publicos de instrucção secundaria do Municipio da Côrte. Disponível em: https://www2.camara.leg.br/legin/fed/decret/1824-1899/decreto-2006-24-outubro-1857558097-publicacaooriginal-78997-pe.html. Acesso em: 15 dez. 2019. 
BRASIL. Decreto n. 2434, de 22 de junho de 1859. Disponível em: https://www.diariodasleis.com.br/legislacao/federal/195536-crua-huma-cadeira-para-oensino-religioso-no-imperial-collegio-de-pedro-segundo-e-marca-os-vencimentos-dorespectivo-professor.html. Acesso em: 20 maio 2019.

BRASIL. Decreto n. 6.884, de 20 de abril de 1878. Altera os Regulamentos do Imperial Collegio de Pedro II. Disponível em: https://www2.camara.leg.br/legin/fed/decret/18241899/decreto-6884-20-abril-1878-547470-publicacaooriginal-62227-pe.html. Acesso em: 11 nov. 2019.

BRASIL. Decreto n. 7107, de 11 de fevereiro de 2010. 2010b. Promulga o Acordo entre o Governo da República Federativa do Brasil e a Santa Sé relativo ao Estatuto Jurídico da Igreja Católica no Brasil, firmado na Cidade do Vaticano, em 13 de novembro de 2008. Disponível em: http://www.planalto.gov.br/ccivil_03/_ato20072010/2010/decreto/d7107.htm. Acesso em: 12 dez. 2019.

BRASIL. Diretrizes Curriculares Nacionais para os cursos de licenciatura em Ciências da Religião. Parecer CNE/CP n ${ }^{0}$ 12/2018 homologado pela Portaria n. 1.403, publicada no D.O.U. de 28 dez. 2018b. Disponível em:

http://portal.mec.gov.br/dmdocuments/pces01_09.pdf. Acesso em: 26 maio 2019.

BRASIL. Lei de 15 de outubro de 1827. Disponível em:

https://www2.camara.leg.br/legin/fed/lei_sn/1824-1899/lei-38398-15-outubro-1827566692-publicacaooriginal-90222-pl.html. Acesso em: 15 fev. 2019.

BRASIL. Lei n. 9.394, de 20 de dezembro de 1996. Estabelece as diretrizes e bases da educação nacional. Disponível em: http://www.planalto.gov.br/ccivil_03/leis/l9394.htm. Acesso em: 12 dez. 2019.

BRASIL. Ministério da Educação. Base Nacional Comum Curricular. 2017. Disponível em: http://download.basenacionalcomum.mec.gov.br/. Acesso em: 22 maio 2019.

BRASIL. Ministério da Educação. Conselho Nacional de Educação. Portaria CNE/CES n. 3, de $1^{\circ}$ de março de 2018a.

BRASIL. Ministério da Educação. Conselho Nacional de Educação. Resolução CNE/CEB n. 7/2010. 2010a Disponível em: http://portal.mec.gov.br/dmdocuments/rceboo7_10.pdf. Acesso em: 25 maio 2019.

BRASIL. Ministério da Educação. Conselho Nacional de Educação. Resolução CNE/CP n. 2/2017. 2017. Disponível em:

http://basenacionalcomum.mec.gov.br/images/historico/RESOLUCAOCNE_CP222DEDEZ EMBRODE2017.pdf. Acesso em: 25 maio 2019.

BRASIL. Ministério da Educação. Portaria n.1.570, de 20 de dezembro de 2017. Diário Oficial da União, Brasília, n. 244, 21 dez. 2017, p. 146. Disponível em:

https://abmes.org.br/legislacoes/detalhe/2459. Acesso em: 26 maio 2019.

BRASIL. Regulamento n. 8, de 31 de janeiro de 1838. Contém os Estatutos para o Collegio de Pedro Segundo. Collecção das Leis do Império. Tomo 1, Parte $2^{\mathrm{a}}$., secção $6^{\mathrm{a}}$. Disponível em:

http://www.histedbr.fe.unicamp.br/navegando/fontes_escritas/3_Imperio/regulamento\%2 on.\%208\%20-1838\%20\%20estatutos\%20para\%200\%20col\%2opedro\%20ii.pdf. Acesso em: 15 fev. 2019. 
BRESSLER, Sonia; SEMARD, David. La laicité. Rosny: Bréal, 2006.

CARNEIRO, Moacir Alves. LDB Fácil: leitura crítico compreensiva artigo a artigo. 5. ed. Petrópolis: Vozes, 1998.

CECCHETTI, E. A laicização do ensino no Brasil (1889-1934). 2016. 322 f. Tese (Doutorado em Educação) - Universidade Federal de Santa Catarina, Florianópolis, 2016.

CONDORCET, M. J. A. N. C. Rapport et projet de décret sur l'organisation générale de l'Instruction publique. [1793]. Enfance, tome 42, n. 4, p. 7-32, 1989. [1793]. Disponível em: https://www.persee.fr/docAsPDF/enfan_oo13-7545_1989_num_42_4_1898.pdf. Acesso em: 21 maio 2019.

CONDORCET, M. J. A. N. C. Cinq mémoires sur l'instruction publique (1791). Présentation, notes, bi-bliographie et chronologie part Charles Coutel et Catherine Kintzler. Paris: Gar-nier-Flammarion, 1994. (Texte integral).

CONFERÊNCIA NACIONAL DOS BISPOS DO BRASIL. Boletim Semanal, Brasília, n. 300, o8 fev. 1996.

CUNHA, Luiz Antonio. Educação e religiões: a descolonização religiosa da escola pública. Belo Horizonte: Mazza Edições, 2013.

CURY, Carlos Roberto Jamil. A educação e a primeira constituinte republicana. In: FÁVERO, Osmar (org.). A educação nas Constituições Brasileiras (1823-1988). Campinas: Autores Associados, 2005. p. 66-80.

CURY, Carlos Roberto Jamil. Ideologia e educação brasileira: católicos e liberais. São Paulo: Cortez, 1986.

DOMINGOS, Marilia De Franceschi Neto. Escola e laicidade: o modelo francês. INTERAÇÕES - Cultura e Comunidade / v. 3 n. 4 / p. 153-170 / 2008. Disponível em: http://periodicos.pucminas.br/index.php/interacoes/article/view/6714. Acesso em: 21 maio 2019.

GRUEN, Wolfgang. Ensino Religioso em movimento. In: BOEING, Antonio e ILTOZ, Sonia de (org.). O Ensino Religioso no Projeto Pedagógico Pastoral Salesiano II. Brasília: Rede Salesiana de Escolas, 2013. Páginas, 125 a 147. (Capítulo VI)

GRUEN, Wolfgang. Ensino Religioso Escolar - verbete. In: PEDROSA, W. M. et al. Dicionário de catequética. São Paulo, Paulus, 2004. p. 411-421.

GRUEN, Wolfgang. O “Ensino Religioso" na escola. Belo Horizonte: Instituto Central de Filosofia e Teologia - UCMG, 1974. 12p

MOACYR, Primitivo. A instrução e o Império (subsídios para a História da Educação no Brasil): 1823-1853. São Paulo: Companhia Editora Nacional, 1936.

PIEPER, Frederico. Aspectos históricos e epistemológicos da Ciência da Religião no Brasil: Um estudo de caso. Numen: revista de estudos e pesquisa da religião, Juiz de Fora, v. 21, n2, jul./dez. 2018, p. 232-291. Disponível em: https://periodicos.ufjf.br/index.php/numen/article/view/22159. Acesso em: 12 mar. 2020. 
PENA-RUIZ, Henri. Principes fondateurs et définition de laicité. República e laicidade: associação cívica, p. 1, 06 set. 2004. Disponível em: http://www.laicidade.org/wpcontent/uploads/2006/12/obs-communautarisme-2004-09.pdf . Acesso em: 26 maio 2019.

PORTUGAL. Tratado de Amizade, Commércio, e Navegação entre Sua Alteza Real o Príncipe Regente de Portugal e Sua Magestade Britânnica. Lisboa: Imprensam Régia, 1810. Disponível em: https://digital.bbm.usp.br/handle/bbm/7405?locale=en. Acesso em: 22 maio 2019.

SANGENIS, Luiz Fernando Conde. Gênese do pensamento único em educação: franciscanos e jesuitismo na história da educação brasileira. Petrópolis: Vozes, 2006.

SANTIROCCHI, Ítalo Domingos. Uma questão de revisão de conceitos: Romanização Ultramontanismo - Reforma. Temporalidades: revista discente do Programa de Pósgraduação em História da UFMG, v. 2, n. 2, ago./dez. 2010. Disponível em: <https://periodicos.ufmg.br/index.php/temporalidades/article/view/5387>. Acesso em: 22 maio 2019.

SCAMPINI, Padre José. A liberdade religiosa nas constituições brasileiras. Petrópolis: Vozes, 1978.

SENA, Luzia (org.). Ensino Religioso e formação docente: ciências da religião e ensino religioso em diálogo. São Paulo: Paulinas, 2006.

SILVA, Antônio Francisco da. Idas e vindas do Ensino Religioso em Minas Gerais: a legislação e as contribuições de Wolfgang Gruen. Belo Horizonte: Segrac, 2007.

SILVA, Antônio Francisco da. Modernidade, religião e educação: temas contemporâneros? Um estudo à luz de Hélder Câmara e Álvaro Negromente. Porto Alegre: Letra Viva, 2013.

SIQUEIRA, Giseli do Prado; BAPTISTA, Paulo Agostinho N.; SILVA, Wellington Teodoro da. A Conferência de Medellín: contexto político-eclesial e a posição sobre a Educação e a Juventude. Horizonte: revista de estudos de Teologia e Ciências da Religião, Belo Horizonte, v. 16, n. 50, p. 648-676, maio/ago. 2018. Disponível em: http://periodicos.pucminas.br/index.php/horizonte/article/view/P.21755841.2018v16n5op648/13557. Acesso em: 23 maio 2019.

SIQUEIRA. Giseli do Prado Siqueira. O Ensino Religioso nas escolas públicas do Brasil: implicações epistemológicas em um discurso conflitivo, entre a laicidade e a confessionalidade num estado republicano. Tese (Doutorado em Ciência da Religião). Universidade Federal de Juiz de Fora, Juiz de Fora, Minas Gerais, 2012.

SUPREMO TRIBUNAL FEDERAL - STF. Acordão da Ação Direta de Inconstitucionalidade 4.439/2010, de 27 de setembro de 2017. Disponível em: http://www.sbdp.org.br/wp/wp-content/uploads/2018/10/ADI-4439-DF-Ementa-eRelat\%C3\%B3rio-1.pdf. Acesso em: 22 maio 2019.

ZOTTI, Solange Aparecida. O ensino secundário no Império brasileiro: considerações sobre a função social e o currículo do Colégio Dom Pedro II. Revista HISTEDBR On-line, Campinas, n. 18, p. 29-44, jun. 2005. Disponível em: http://www.histedbr.fe.unicamp.br/revista/revis/revis18/arto4_18.pdf. Acesso em: 15 fev. 2019. 